$\begin{array}{r}\text { Volume and Issues Obtainable at Center for Sustainability Research and Consultancy } \\ \text { Journal of Business and Social Review in Emerging Economies } \\ \text { ISSN: 2519-089X (E): 2519-0326 } \\ \text { Volume 6: No. 4, December 2020 } \\ \text { JSRᄃ } \\ \text { Journal homepage: www.publishing.globalcsrc.org/jbsee } \\ \hline\end{array}$

\title{
A Comparative Study of Perjury in Legal System of Pakistan and Islamic Law
}

\author{
${ }^{1}$ Rashida Zahoor, ${ }^{2}$ Muhammad Fahad Anwar, ${ }^{3}$ Muhammad Asif Safdar, ${ }^{4}$ Jibran Jamshed \\ ${ }^{1 \& 2}$ Assistant Professor, Department of Law, University of Sahiwal, Pakistan, \\ rashidazahoor@uosahiwal.edu.pk,fahad@uosahiwal.edu.pk \\ ${ }^{3}$ Assistant Professor, Principal of Gillani Law College, Bahauddin Zakariya University Multan, Pakistan, \\ principallaw@bzu.edu.pk \\ ${ }^{4}$ Assistant Professor, Department of Law, Islamia University of Bahawalpur, Pakistan, \\ jibran.jamshed@iub.edu.pk
}

\begin{tabular}{l}
\hline ARTICLE DETAILS \\
\hline History \\
Revised format: November \\
2020 \\
Available Online: December \\
2020 \\
\hline Keywords \\
Perjury, Pakistani laws on \\
Perjury, PPC, QSO, Islamic \\
Laws of Swear. \\
\hline
\end{tabular}

JEL Classification

M10, M12

\begin{abstract}
Perjury is one of the crimes that harm criminal justice; Action against criminal justice means behavior that affects people's right to access the justice system or society's right to prosecute and punish criminals. The witness is considered a reason to prove disputes in both legal and criminal complaints, and due to the importance and value of the evidence, perjury has its specific implications. In our criminal justice system, testimony is a way of legal knowledge and reasoning to diagnose crimes committed by the accused. The testimony is not used in criminal matters, and ignoring his way is not against the accused. Consequently, truth is essential, and testimony cannot be used if it is not true. This paper expresses various forms and numerous aspects of perjury along with its definition, discusses perjury as part of the behavioral and psychological approach of sociology, and finally analyzes the laws of Perjury in Pakistan along with the relevant sections of the Pakistan Penal Code, 1860 (PPC), Qanoon and Shahadat Ordinance, 1984 (QSO) and The Oaths Act, 1873 and other Islamic provisions of laws relating to perjury.
\end{abstract}

(C) 2020 Center for Sustainability Research and Consultancy Pakistan under a Creative Commons Attribution-NonCommercial-ShareAlike 4.0

Corresponding author's email address: Jibran.jamshed@ @iub.edu.pk

Recommended citation: Zahoor, R., Anwar, M. F., Safdar, M. A. \& Jamshed, J. (2020). A Comparative Study of Perjury in Legal System of Pakistan and Islamic Law. Journal of Business and Social Review in Emerging Economies, 6(4), 1571-1579

\section{Introduction}

The only purpose of taking evidence in court has always been to allow judges to practice justice after adequately assessing the pros and cons of the litigation in question while keeping the rating scale among the parties concerned. It would be difficult for the court of law to do so unless and as long as the evidence previously presented is truthful, uncontaminated, and free of prejudice. The basic rules for the test of evidence were followed in Pre-Islamic Society of Arabia, early Roman Society, India, Persia, etc. In all legal systems, the oath is one reason for the trial, and a means to resolve hostility in claims for religious and belief reasons. It means that people swear by God and by their religions and beliefs to show that they are correct and accurate in what they deposed. Suppose a person finds out that swearing 
is false, and I shall achieve several effects in the judgment issued by the judge. Swearing is the last resort to prove the case and examine the claims and disputes in civil and criminal cases. Due to the authority of trying to ascertain the cause, perjury will have some effect. In the legal system, this reason generally serves only to settle the dispute. The curse word is used if the complaint cannot be proven in any other way. After introducing the swear word, the plaintiff's reason is not accepted; however, the lawyer's refusal to award the award is useful in the lawsuit and is released based on the above admission. Taking the oath is based on conscience and believes in the oath. By reducing the likelihood of false statements, the legislature predicted the concentration on the dirty word. In Islamic law, the oath is a concept of dignity; even if the lawyer is not one of the followers of monotheistic religions after swearing God, the prosecutor can also take the oath to the sanctities accepted by the above. Based on measures such as the meaning of the subject matter of the complaint, the parties' personality to the dispute, the oath could be focused according to the perspective and discretion of the court in terms of conditions, time, space, and situation state. "I swear to inform the reality, the total truth and to compress the truth" a sentence that is narrated many times in a week in television programs and films. It is therefore known that its meaning is often not marked. However, as soon as he is sworn in court or other officials who continue, he will provide all of the above information regarding reality or violation.

Wrong testimony or false testimony is a curse for any country's criminal justice system. Several innocent people suffered behind bars for ages just because a person had lied to the court. It is encouraging that Pakistan's Supreme Court Judge viewed the extinction of perjury as one of the foundations to reform the criminal justice system. Supreme Court of Pakistan had firmly stated his objective to build a dam against false testimonies and false witnesses. Supreme Court said that those on trial would be sentenced to prison and forbidden to testify again.

Providing false evidence of an oath in a competent jurisdiction is legally known as a violation. It is a grave crime because it delays the method of justice at the center of a system. Perjury as the crime of being under oath could be a serious crime as it upsets the essential objectives of the judicial system "the discovery of reality". Even the well-known and influential have been exposed to effects of violations that embody law enforcement, prison, and legal documents - the tendency to lie sticks to practically every society and civilization.

Furthermore, an individual could also be a habitual traitor and pathological liar. The use of lies is not only subject to cessation but will also be the result of interference. The opposite side of the violation is that under "oath" a lie is formed.

Giving false testimony is a criminal offense in the law of Pakistan. In PPC making false statements at every stage in court proceedings accounts for seven years in jail, while the penalty for making wrong statements in capital cases can be up to life imprisonment. According to the law, the same lender can be sentenced to death because of his fall statement; an innocent person is executed.

\subsection{Definition}

Judicial affirmation of falsehood upon oath and affirmation equivalent to the oath is called perjury. For perjury, there must be a renunciation of what is correct or an assertion of what is false. The declarations criticized must be relevant to the matter which has been initially tried.

The deliberate declaration on a matter of fact, faith, knowledge, or opinion given by a witness as a portion of the evidence, whether or not the evidence is given to the judge in open court or by an affidavit or otherwise, by way of oath or in any manner permitted by law to be substituted for an oath. Such declaration must be known as false by such witness and be intended to mislead the court or person conducting a case.

\subsection{Essential Elements of Perjury}


A witness who is under oath has committed perjury if he makes a statement that the witness knew it was not correct in court or other proceedings. The witness's statement in court has to be "material" on the matter. It means that statement and material before the court must connect to the litigation, investigation or inquiry of the proceeding. Following are the essential elements of perjury:-

\section{- Perjury only takes place under oath}

The witness, who makes a declaration, must swear by a judge, a notary or other official to tell the truth before someone who is authorized to take the oath under the relevant law. Also, the proceedings must be 'in front of a competent authority' authorized by the state's law. For instance, an authority that has started an inquiry outside its powers will not be considered competent proceeding (Reid Jr, 1999). In such a case, the accused will not be liable for perjury as for perjury, authority or court must be empowered to record evidence (Mst. Maryam Hayyat Case, PLD 2013 Karachi 194, 2013).

- Perjury involves statement

Keeping quiet or denying a witness to give a statement will not be considered perjury, but it may lead to other punitive charges. If testimony is accepted in the proceedings and the witness authenticates it as incorrect scripture under oath will be considered perjury.

- With an intention to mislead

A witness submitting before the competent authority must know that the declaration it makes is false and he must make it to deceive the court.

- Only incorrect statements are perjury

Incorrect statements of a witness resulting from misperception, memory loss, or errors are neither false and nor will be considered perjury. Contradiction in evidence may be considered perjury if one witness made self-contradictory statements and prosecutors may prove perjury because selfcontradictory statements were false.

- Contradictory Statements may lead to perjury

A witness's statement must be observed and read as a whole by the court/authority. If, when questioned at one point during evidence, a witness claimed that he did not recall an incident. However, he undoubtedly recollected aspects of the event when questioned future than he may have committed perjury. However, if evidence of a witness is inconsistent, the proceeding before the authority or the court is not perjury.

- Statement in court or another trial

Inappropriate comments made outside of official hearings do not constitute perjury. For example, a deponent is lying to his prosecutor, who takes outlines to draw up an affidavit that the deponent has not committed any perjury. However, if the deponent signs the affidavit later with the false statement that it includes, then perjury is considered. Affidavits, written declarations, written responses to courts or public bodies and proceedings statements are subject to perjury in the prevailing state laws.

- "Substantial" testimonials can be perjury

The wrong statement must manipulate the proceeding. This implies, in a matter of the proceeding, it must have a connection to the matter. It involves an incorrect statement that is likely to mislead or hinder the investigation or case. This implies that a lie under oath about an issue irrelevant to the proceeding is not regarded as perjury. For example, it would not amount to perjury to incorrectly state in a proceeding that "I never update my Facebook page at work" and it had nothing to do with social networking at work.

- A substantial statement that is unnecessary may be a perjury

Where false evidence does not affect a case's outcome, witness lying may be accused of perjury. For example, an ex-police officer is on trial for participating in a gambling operation, and some witnesses have affirmed his involvement. That ex-police officer denied any involvement, however. His denial would be a strong statement, although it did not affect the court's finding of guilt because the court had evidence from the other witnesses to rely on. 


\subsection{Main Reasons for Giving False Evidence}

Commonly main reasons for giving wrong evidence are as under:-

i. The desire to cause damage to the party in civil or criminal proceedings, either because of the adverse party's inducement or pressure or because of the witness' dispute with the adverse party or

ii. To assist the suspect in criminal proceedings or civil litigation, either under coercion, threat or inducement,

iii. To avoid suffering rage of a party to which witness must submit evidence.

In many cases, witnesses evade appearing before courts to give a statement and show unawareness of disputed matter to avoid aggravation usually faced by witnesses while appearing in the courts. Witnesses also considered it a waste of time and unnecessary embarrassment. It was also noted in many criminal cases that, on the one hand, some witnesses give false evidence at police request to make the prosecution case successful. Despite being inclined to give real evidence, other witnesses are abstained from fear of retribution, either by the police or the accused party.

\subsection{Lying and Environmental Approach: An Behavioral Analysis}

"Lying" is a behavior that seems prevalent in different cultures, ages, etc. Lying also seems to be linked with some of the social problems. It frequently interrupts social connections, causes problems in places of work, and corrupts politics. For example, in lying behavior, people are considered liars, whereby lying is considered to exist in the individual. Because of this, the individual is liable for their lying behavior. Thus, thinking of environmental factors leading to the development and persistence of lying is avoided as the problem of lying is presumed to exist in individuals (Fryling, 2016).

Not surprisingly, lying can grow very early in the life of every child. In childhood, most behavior is secure through instant incidents. Children learn to take food, which is reinforced by contact with food and by taking puppets from their age fellows or friends when nobody watches, all these behaviors are immediately reinforced. Much of the young child's behavior can be considered impulsive in this sense. Indeed, both past and future are verbal constructs (Hayes, n.d.). However, as children grow a sophisticated verbal range. For example, they start responding to several derived stimulus issues.

While building on childhood practices, adult situations are reasonably separate in their complexity that deserves special attention. In line with our analysis, lying may occur in adulthood as it was not sufficiently conditioned as an aversive stimulus condition. Usually, some adults may lie because they have never been taught lying was "bad." Lying, as defined by an aversive stimulus, is not a form of stimulus to avoid. If the lying context's remaining features are not avoided, the positive and negative strengthens both direct and derived. This condition makes lying cases somewhat probable (Fryling, 2016).

\subsection{Pathological Liars}

Pathological lying has been outlined as "falsification entirely disproportionate to any discernible finish visible, is also in-depth and sophisticated, and should manifest over several years or perhaps a lifetime".

- Tell compulsive lies while not a transparent motive

- Told of times and obsessively

- Told for no apparent reason or gain

- Continuous

- Told to create the teller seem heroic or the victim

- Not deterred by guilt or risk of obtaining acknowledged

Examples of pathological lying:

- Making a false history, like expression they have achieved or experienced one thing they haven't

- Claiming to own a grievous unhealthiness that they do not have 
- Telling lies to impress others, like expression they are associated with a superstar

\subsection{Pakistani Laws Dealing with Perjury: 1.6.1 Perjury under PPC}

Section 191 of PPC deals with Perjury in Pakistan (PPC, 1860). This section contains the following elements: -

\subsubsection{Giving the Wrong Evidence}

PPC defines "giving of false evidence" This definition cannot be said to include any common principle of universal application as such. An individual should always express the truth is a moral belief, but not a legal principle.

\subsubsection{Statement on Oath}

When an individual is "legally bound by an oath" a person authorized to administer it must give sufficient legal oath. The person to whom such oaths can be administered must be competent. The oath must have been made before giving a statement.

\subsubsection{Court not Appropriately Established}

An individual who makes false statements on oath before a court or authority that is not correctly constituted cannot sentence for perjury.

\subsubsection{Wrong Verification}

Perjury is a false statement made through wrong verification, and it constitutes an offense punishable under S. 193 PPC.

\subsubsection{Declaration}

If an individual makes a false statement that any law binds him, he would be guilty of perjury. For example, if a court officer makes a false statement of how a "warrant of sale" was issued, he will be guilty of an offense under S. 191 of PPC.

\subsubsection{Giving False Statement}

To constitute an offence of perjury, the case's decision in which it is given need not provide false evidence on a material question of law or fact. For perjury, it is sufficient that the false evidence is deliberately given if the person making that statement deliberately makes it known that it is false and intends to mislead the court to presume it is true. But if the false statement is not directly related to a fact in the case, but only to incidental matters, it should be taken into account in the sentence.

\subsubsection{The Statement is not Read over to the Person}

If a witness's false statement was not read as required by S.360 of the CrPC, the defect was deemed curable and would not be fatal to the proceedings (IDO Case, PLD 1951 Quetta 14, 1951).

\subsubsection{Information of Falsehood is Required}

An individual cannot be convicted of perjury unless he knows that his statement is false or thinks it is false or does not believe it is true. An individual does not commit an offense under PPC S.193 by merely mentioning something untrue in a complaint or written statement or omitting something from the complaint or written statement. Excluding the name of one of the decree-holders in a decree, the application is not an offense under S. 193.

\subsubsection{Proof}

There must be absolute certainty about the statement's falseness and the absence of faith by the accused in his own words to support a conviction under S 193 of the PPC. The burden is on the prosecution to show that the witness' statement in his testimony, or any document produced in court, was false as 
defined in S. PPC 191. It cannot be presumed that the statement made before the police during the investigation by the witness spoke the truth and, based on that assumption, it cannot be held that he gave false evidence in the testimony of the witness before the court and thus committed an offence under S. PPC, 193.

\subsubsection{Perjury in Qanoon-e-shahadat Ordinance, 1984}

Competency of witnesses under Article 3 of the 1984 Qanoon-e-Shahadat Order;

Article 3 provides that each person is competent to give evidence in court (QSO, 1984). The only restriction to regulate the witness' ability is court satisfaction that the person before the court can provide evidence. However, the article itself qualifies this general principle by providing exceptions. One of Article 3's exceptions is perjury. His exception says perjury is an offence; it means deliberately giving false evidence in court. Any person sentenced for perjury is excluded from giving evidence in court. Such a person is not a truthful witness. However, if the person repents in the court's opinion, the evidence can be accepted.

\subsubsection{The 'Tazkiya-al-Shahood'}

It is a method of inquiry to be implemented by the court to govern a witness's trustworthiness on the standard of Islamic injunctions that require piousness, credibility and truthfulness of the witness. It is only acceptable in Hadood laws and not in Tazir (Shahid Orakzai Case, PLD 2017 FSC 63, 2017).

\subsubsection{Ways of checking Tazkiya:}

According to Fatawa-e Alamgiry, there are two ways of checking Tazkiya;

1. Capability of the witness can be examined openly

2. Capability of the witness can be checked through investigation secretly

\subsubsection{Persons can also aid in checking Tazkiya:}

Following persons can also aid in checking Tazkiya;

1. Persons trustworthy;

2. Persons familiar with the witness's life and the character whose capability is being tested.

Even if need in respect of Tazkiya-al-Shuhood will be accomplished at the top of the testimony and interrogation of a witness, the suspect should be supplied with another chance of cross-examining even at that stage the witness in respect of his standing as claimed to be a just/Adil witness. It is solely through the method of interrogatory of a witness in respect of a matter asked of him to fulfill the wants of Tazkiya-al-Shuhood that associate suspect will, on the one hand, impeach the integrity and quality of a witness and by an equivalent process modify the judicature to fulfill late requirements of inquiry to succeed in a conclusion that the witness could be a just/Adil witness which his proof need not be discarded however must be relied upon to choose the case (Wajid Umar Case, 1992 PCr.LJ 1536, 1992).

\subsubsection{Impeaching a Witness}

When evidence is given under oath during the hearing, the adverse party can usually challenge the authenticity of evidence through cross-examination. The opposition's tools express flexibility to analyze witnesses' authentic ability to look at certain witnesses' occurrences or memory. The opponent may also challenge the witness's necessary quality by allowing witnesses to tell reality apart from those facts. Such a way in proceedings can be called "impeaching witness", and it is rapid attack on the witnesses' character (Naeem Case, 2019 PCrLJ Karachi 305, 2019).

\subsubsection{Impeaching a Witness through Previous Inconsistent Statements}

A person's own statements confronting the witness on the opposite side, which are at odds with the person's evidence, could be common to impeach. However, the opposing party cannot introduce the statement without allowing the witness to clarify (Mehdi Khan Case, 2015 PCrLJ Lahore 26, 2015). 


\subsubsection{Implementation of Oath Laws in Pakistan}

The Pakistani courts barely apply laws punishing perjury for punishing liars. That is why they do not perform the theory of deterrent practically. In August 2018, during the case regarding judicial reforms, the Sindh High Court (SHC) Registrar replied that "the SHC and its subordinate courts have not prosecuted even a single person over the past almost three years for perjury under Sections 193-196 of PPC" (Sehgal, 2019).

The public thinks there are many excellent ways to get away with lies in court, even if the liars are identified during proceedings even though they have no fear of punishment. Witnesses lying in court against Aasia Bibi are accountable for her long-term imprisonment. Supreme Court acquitted Aasia Bibi, but no action was taken against witnesses for perjury (Wikipedia, n.d.).

Perjury is an exclusively criminal offense as it weakens the court's very purpose, country laws, and judiciary at large. Pakistan's honest citizens currently feel hopeless to reach court in disputes because they are not sure that justice will prevail. Gulzar Ahmad's new Supreme Court Chief Justice (CJP) style may differ from his predecessors to bring the rule of law back into the system. Justice Gulzar Ahmad took up the abolition of perjury as one of the foundations of criminal justice reform and his involvement in restoring Pakistan's judiciary. He assured that the law punishing perjury would be implemented with full spirit.

Justice and truth are closely linked and inter-reliant. According to Islamic teachings established truthfulness is a Muslim's central characteristic. Once, Hazrat Muhammad PBUH offered morning prayer, and after he has finished his prayer, he stood up, saying three times: False witness was made equivalent to attributing a partner to Allah. Then he recited: avoid the abomination of idols and avoid speaking falsehood as pure people of Allah's faith, associating nothing with Him.

The discussion of Articles 62 and 63 of the Constitution of the Islamic Republic of Pakistan, 1973, and the demands we heard to delete them from this fundamental law of our country sign that being trustworthy is no longer considered a central value.

A judiciary that allows deliberate falsehood is doomed to fail, and a society that accepts destroying it. The truth is that the foundation of the Criminal Justice System. In application No. 231 of 2019 before the Supreme Court of Pakistan, Chief Justice of Pakistan stated that "Justice is that the essence and foundation of civil society can compromise the truth is a compromise for society's future as a simple, genuine and civilized society" (Khizar Hayyat Case, PLJ 2019 Supreme Court (Criminal) 265, 2019).

Under Pakistani law false witnesses can be imprisoned up to life, it was said by said former Pakistani chief justice Asif Saeed Khosa during a case of false testimony in Mazhar Hussain's famous murder case. In this case, a police officer, namely Mazhar Hussain, was murdered in Faisalabad, Pakistan. A witness Muhammad Arshad appeared in the witness box. He said, "he was shot in the arm, and he injured out the bit, and I may be punished in the hereafter if I have lied in court." During the hearing, Pakistan's chief justice said that the witness should refrain from talking so much and told him that his medical report says a pellet or bullet did not hit him. CJP also added that "you said that you felt the pellet on your leg too, were you wearing iron pants? A person was sentenced to death because you lied in court. The law says that people who give false testimonies should be imprisoned for life." The court rejected his statement and sent his case to the Anti-Terrorism Court (SAMAA |Zulqarnain Iqbal, 2019).

\subsection{Islamic Laws about Perjury}

In Islam, very great pressure has been laid on the significance of proper evidence. In the Holy Quran in "Sura-e-Yusaf," it has been provided that when Zulekha falsely accused Hazrat Yusaf of arrogant conduct and no clear evidence was available, except the inconsistent statements of both parties. It was suggested that the shirt of Hazrat Yusaf might be inspected and if it was found to be torn from the front 
than Zulekha's allegation is correct, but in case the shirt was found torn from the back, Hazrat Yusaf is innocent, and after inspection, Zulekha was found guilty of the false allegation.

\subsection{Verses of the Holy Quran}

The following verses of the Holy Quran are dealing with the matter of giving testimony:

"And do not mix the truth with falsehood or conceal the truth while you know [it]."(Quran 2:42)

"And let not the witnesses refuse when they are called upon." (Quran 2:282)

"And do not conceal testimony, for whoever conceals it his heart is indeed sinful." (Quran 2:283)

"O you who have believed, be persistently standing firm for Allah, witnesses in justice, and do not let the hatred of a people prevent you from being just. Be just that is nearer to righteousness. Moreover, fear Allah; indeed, Allah is acquainted with what you do." (Quran 5:8)

"O you who have believed, be persistently standing firm in justice, witnesses for Allah, even if it be against yourselves or parents and relatives." (Quran 4:135)

"So follow not [personal] inclination, lest you not be just. And if you distort [your testimony] or refuse [to give it], then indeed Allah is ever, with what you do, acquainted." (Quran 4:135)

"And establish the testimony for [the acceptance of] Allah." (Quran 65:2)

"And we will not withhold the testimony of Allah. Indeed, we would then be of the sinful." (Quran 5:106)

"And avoid false statement." (Quran 22:30)

"And they who do not bear witness to what is false." (Quran 25:72)

From the above verses of the Holy Quran, testifying to its proper meaning and weight is a compulsory duty, and those who stand firm in their testimonies are among the people of morality and faith. If there are no other witnesses that would allow justice to be done, and there is fear that somebody's right may be lost, testifying becomes the few witnesses' responsibilities. Islam commands testimony and prohibits hiding it as hiding evidence is condemned in Islam and disliked by Allah. Giving false testimony has many sins that promote falsehood against the truth and promote injustice and violence against justice. It also erases justice and equity and jeopardizes public security.

\subsection{Traditions of the Holy Prophet (PBUH)}

According to the Holy Prophet (PBUH), false testimony is one of the extreme evils, and the following hadith verifies the importance of giving true testimony:

" Hazrat Anas (RA) said the Holy Prophet (PBUH) was once asked about great sins.

i. Joining others to worship Allah;

ii. To undutiful to one's parents;

iii. Kill someone (which Allah has forbidden to kill)

iv. Giving false evidence."

Hazrat Abdullah (RA) narrated that the Holy Prophet (PBUH) said that if somebody makes a false oath to unjustly get a Muslim's property, Allah will be angry when he meets Him (Bukhari, n.d.).

\subsection{Enforcement of Hadd Ordinance, 1979}

Under section 2 of the Offence of Qazf (Enforcement of Hadd) Ordinance, 1979 offence of Qazf had been provided.

The Holy Quran dealing the offence of Qazf commands that:

"And those who accuse chaste women and then do not produce four witnesses - lash them with eighty lashes and do not accept from them testimony ever after. And those are defiantly disobedient." (Quran 24:4)

"And those who accuse their wives [of adultery] and have no witnesses except themselves - then the witness of one of them [shall be] four testimonies [swearing] by Allah that indeed, he is of the truthful." (Quran 24:6)

"And the fifth [oath will be] that the curse of Allah be upon him if he should be among the liars." (Quran 24:7) 
"But it will prevent punishment from her if she gives four testimonies [swearing] by Allah that indeed, he is of the liars." (Quran 24:8)

"And the fifth [oath will be] that the wrath of Allah be upon her if he was of the truthful." (Quran 24:9)

The above verses highlight Islam's position on the compulsory standard of evidence to achieve. The Holy Quran places great importance on the need to meet the necessary standard of evidence. A person who lifts Zina's allegation but does not comply with the evidentiary standards provided must be punished.

\section{Conclusion}

Individuals who commit perjury are complicit in justice's failure and crooked the legal process of exposing the truth. Bearing false evidence attracts severe, legal penalties in a well-functioning justice system. In an unethical, cruel system, however, giving false evidence is treated as daily detail. Lower courts are rife with alls offering a price for false evidence. Indeed, an accused's life may be in an individual's hands who lives by misleading the court. It is not because there is no perjury law.

The reason perjury is so prevalent in the criminal justice system is that it is so rarely enforced that it may not exist. It emerged in August 2018 that over the past three years, not a single individual is prosecuted for perjury in the SHC and its subordinate courts. False testimony is not always bought, but may sometimes result from witness pressure. Therefore, witness protection must be much more substantial. Enhanced forensic services would also reduce witness trust. Perjury cannot be isolated. It is just one feature of the consistent, appalling criminal justice system.

In Pakistan whoever gives false evidence or interferes with oral or documentary evidence is liable for imprisonment up to seven-year, and it may also be extended up to the imprisonment of life.

\section{References}

Bukhari, S. (n.d.). Sahih Bukhari. https://d1.islamhouse.com/data/en/ih_books/single/en_Sahih_AlBukhari.pdf

Fryling, M. J. (2016). A developmental-behavioral analysis of lying. International Journal of Psychology and Psychological Therapy, 16(1), 13-22.

Hayes, S. C. (n.d.). Hayes, SC \& Hayes, LJ (1992). American Psychologist, 47, 1383-1395.

Wajid Umar Case, 1992 PCr.LJ 1536, (1992).

Mehdi Khan Case, 2015 PCrLJ Lahore 26, (2015).

Naeem Case, 2019 PCrLJ Karachi 305, (2019).

IDO Case, PLD 1951 Quetta 14, (1951).

Mst. Maryam Hayyat Case, PLD 2013 Karachi 194, (2013).

Shahid Orakzai Case, PLD 2017 FSC 63, (2017).

Khizar Hayyat Case, PLJ 2019 Supreme Court (Criminal) 265, (2019).

PPC. (1860). Pakistan Penal Code. http://www.pakistani.org/pakistan/legislation/1860/actXLVof1860.html

QSO. (1984). Qanun-e-Shahdat Order. https://punjabpolice.gov.pk/system/files/qanun-e-shahadat-order1984.pdf

Reid Jr, C. J. (1999). The Fundamental Freedom: Judge John T. Noonan, Jr.'s Historiography of Religious Liberty. Marq. L. Rev., 83, 367.

SAMAA | Zulqarnain Iqbal. (2019). Fake witnesses can be imprisoned for life under Pakistani law: top judge. http://library1.nida.ac.th/termpaper6/sd/2554/19755.pdf

Sehgal, I. (2019). Fighting perjury in Pakistan. Dailytimes. http://library1.nida.ac.th/termpaper6/sd/2554/19755.pdf

Wikipedia. (n.d.). Asia Bibi blasphemy case. https://en.wikipedia.org/wiki/Asia_Bibi_blasphemy_case 